\title{
ANALYSIS OF A UNIVERSITY PARKING LOT SYSTEM THROUGH THE USE OF DISCRETE-EVENT SIMULATION
}

\author{
Ricardo Torres $^{(\mathbf{a})}$ Jenaro Nosedal-Sanchez $^{(\mathbf{b})}$ \\ (a) Faculty of Engineering, UNAM, Ciudad Universitaria, Ciudad de México, México \\ (b) Cátedra Conacyt, Facultad de Ingeniería, Universidad Autónoma del Estado de México, Toluca, México \\ (a) ricardtm@unam.mx, ${ }^{(b)}$ jnosedal@,conacyt.mx
}

\begin{abstract}
The management of parking lots in large cities has become one of the most complex problems to solve as this is influenced by many variables, additionally these spaces directly influence the level of service and productivity of many companies. This article proposes the use of the simulation of discrete events to analyze the impact of the changes in the access policies to a pair of parking lots in the Faculty of Engineering of the UNAM in Mexico City, some of the proposed indicators are: number of users not served by saturation (parking spaces not available), maximum number of users looking for a parking space at the same time, average search time of a parking space in case of saturation and number of parking spaces occupied throughout the day.
\end{abstract}

Keywords: parking lot, access policies, discrete event simulation, key performance indicators.

\section{INTRODUCTION}

Parking facilities are usually exposed to long periods of saturation or occupation rates near the maximum along the day due to high demand, this is especially prevalent in busy cities (Barata, 2011). However, in parking facilities that belong to private buildings like universities, the saturation problem has more to do with demand unbalances during specific time frames (peak hours). This problem is directly related to the existence of different schedules of the facilities' users. While some of the users stay in the facilities for long periods, ( 8 hours or more for full-time staff), other users' activities require them to stay for shorter periods (less than 4 hours, for instance, part-time staff or even shorter for instructors). Furthermore, some users need to transit between different buildings on the campus, which sometimes requires using different parking facilities for convenience, which means the parking spots' occupation fluctuates throughout the day, even when the actual demand for the whole system is the same.

Parking facilities are difficult to manage due to demand fluctuation. Also, it is expensive and difficult to add capacity (Teodorović, 2016), the space in a facility such a university is often better used for other purposes rather than parking facilities. Moreover, increasing parking density (for instance using platforms) is difficult to justify and fund. Thus, parking spaces are a critical resource that requires the adoption of different usage policies to provide the best service possible to their users (Fontaine 2005).

The present research seeks to analyze the current management and performance of the parking facilities that belong to the Faculty of Engineering of UNAM in Mexico City. The parking facilities provide service to full-time professors, part-time teachers, and administrative Faculty Personnel, and has eight parking lots distributed around the Faculty's buildings. The scope of this research is to perform the analysis of two of the eight parking lots that the Faculty has, the ones with the highest and lowest demand. The aiming is to provide an assessment and performance comparison of the current and previous operation of the parking lots, with the ultimate objective of increase the effective utilization of the parking lots and improve the service provided.

\section{PROBLEM DESCRIPTION}

Currently, there are 594 parking spaces distributed in eight parking lots, during 2018, 1,731 users were served (part-time professors, full-time professors, academic technicians, and administrative staff). Based on empirical observations, the existence of saturation periods had been detected in specific parking lots. These events suggest the existence of demand imbalances that cause some parking lots to become quickly saturated, and others to have low utilization during the same time windows. It is worthy to mention that currently the service is provided free of charge for all the authorized users, so there is no opportunity to modify the demand using push factors like pricing, the approach described in (Sweet, 2019) and also discussed in (Yan, 2019).

This research focuses on the simulation and analysis of two specific parking lots: "South 3" which has the highest demand of all "South" parking lots, and "South 4" which has the lowest demand for the "South" 
parking lots. These parking lots are located next to each other, as depicted in Figure 1.

Figure 2 shows the demand evolution in terms of the total number of services or events recorded in 2015, 2016 and 2017 for each of the two facilities under analysis. It can be observed that annual demand increases for parking lot "South 3, it can be observed an increase of 5.48\% between 2015 and 2017. As for the parking lot "South 4", a percentage demand decrease of $44.35 \%$ between 2015 and 2017 is observed.

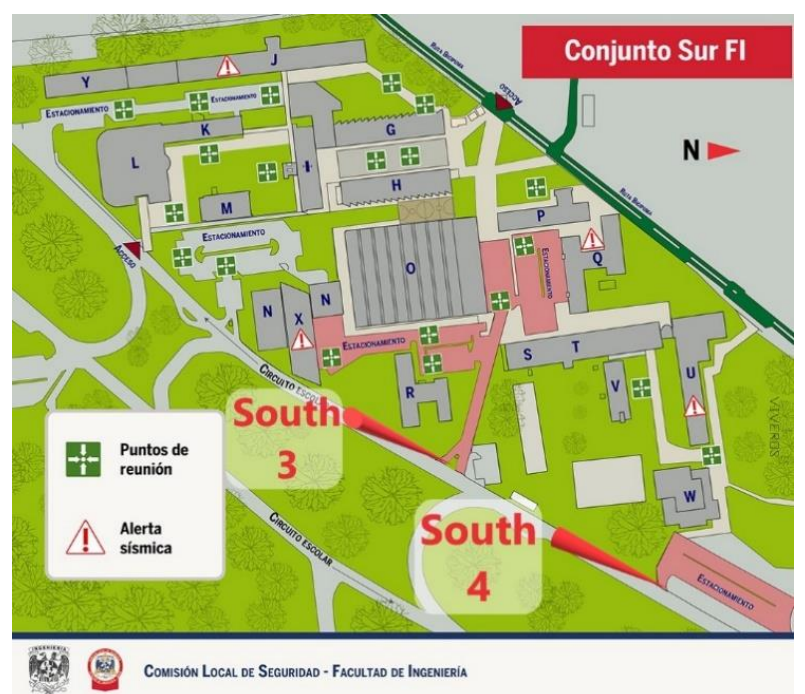

Figure 1: Parking lot locations map. Obtained from the UNAM Faculty of Engineering's Local Safety Commission

at http://www.administracion.ingenieria.unam.mx/webcls/ paginas/pdf/puntos_reunion_cs.png (April 2019)

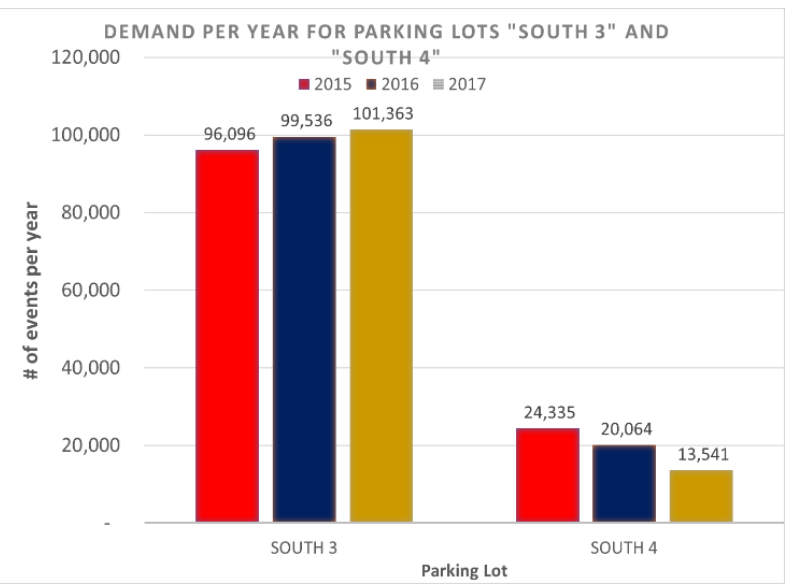

Figure 2: Demand per year for parking lots "South 3" and "South 4", during the years 2015, 2016, and 2017

\section{METHODOLOGY}

To be able to simulate and analyze the behavior of both parking lots in time, aiming to establish a diagnosis of the periods in which the parking lots are saturated and the magnitude of the capacity shortages, the parking lots will be modeled using a Discrete Event Simulation approach.
This approach allows to analyze the behavior of the system over a period of time, as well as to register the interdependencies between the elements of the system (entrance of the parking lot, spaces of parking and exit of the parking lot), as well as the inherent variability to the types of users that they use parking lot (time spent in the parking lot).

The deployed methodology can be summarized by the following five steps:

1. Process understanding and description,

2. Definition of expected outputs to analyze,

3. Implementation of the process using a discrete event simulation framework (FlexSim 2018),

4. Execution of several experiments to analyze the current operation vs the previous operation on the process, and

5. Discussion of the results considering the performance of the system (service level and utilization rate for the parking facilities).

\subsection{Parking lot process and users}

The process of parking in the Faculty of Engineering (in their eight parking lots) can be described by three events:

1. Access the parking lot.

2. Use of parking space.

3. Exit the parking lot.

This process is shown in Figure 3.

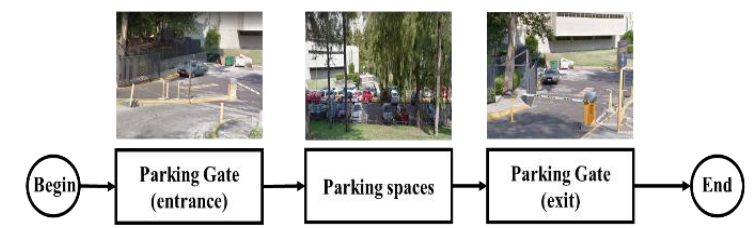

Figure 3: Parking Process in the Faculty of Engineering, UNAM, Mexico City

Both entrances (for South 3 and South 4 parking lots) are located on the same street called Exterior School Circuit, both have a parking gate (for entrance and exit) and independent and fixed capacity (number of parking spaces).

Parking gates (entrance and exit) works with a proximity sensor, for that purpose, one card with a sensor on it is provided to each authorized staff member. Then the cards must be used to have access and to exit the parking lot with a vehicle.

Parking spaces are not assigned to a specific staff member, then all users are entitled to select any of the available places. However, if there is not available space, once in the parking lot, the users can circulate through the parking lot until finding an available space or can drive to the exit gate to leave the parking lot without being served.

The parking lots South 3 and South 4 (and in general the eight parking lots of the Faculty of Engineering at UNAM) serve the following types of users: 
- part-time teachers, these users are instructors who teach one or two subjects at the Faculty of Engineering.

- full-time professors, these users, are teaching or research fellows who have to carry out the following activities: teaching, service and research, among other activities, usually each has an assigned office, however they may need to perform some activities in different buildings managed by the Faculty of Engineering.

- academic technicians, these users deal and manage several activities, for instance: support in the management of laboratories, maintenance of equipment and facilities and in some cases teaching; they can be have an office assigned and also develop activities different buildings managed by the Faculty of Engineering.

- administrative staff, these users are responsible for the non-academic support activities of the Faculty of Engineering; they are assigned to offices and normally do not deploy activities in other buildings managed by the Faculty of Engineering.

Due to the imbalanced saturation observed at certain parking lots during specific day time frames, the administration of the parking lots elaborated some rules to restrict the use of the parking lots based on the types of users in July 2016.

These new rules took effect on the second term of the academic year 2016 (August to December 2016), before that, all users were allowed to use of the parking lots any time they needed, without any day or time restriction.

For the new rules, two types of users were identified, those that require access without time restriction (full time professors, academic technicians and administrative staff) and those that should have access to use the parking at specific times (part-time instructors).

Table 1 shows the two time windows established to restrict the use of the parking lots for part-time instructors, part time instructors assigned for morning sessions can use the parking lot from 3 a.m. to 5 p.m., and similarly, instructors assigned for afternoon sessions, can use the parking facilities from 1 p.m. to 12 a.m.

Table 1: Part Time Instructors' parking time windows

\begin{tabular}{|c|c|}
\hline \multicolumn{2}{|c|}{ Time windows } \\
\hline Morning & 03:00 am to 05:00 pm \\
\hline Afternoon & $01: 00 \mathrm{pm}$ to $12: 00 \mathrm{am}$ \\
\hline
\end{tabular}

\subsection{Input and output variables}

The input variables for the system (parking lots) are the following:

- arrival times of the users to the parking lot,

- time spent by the users in the parking lot,

- $\quad$ service times at the entrances and exits of the parking lot.

The output variables, which in this case also correspond to Key Performance Indicators (KPIs), should help to measure whether the implemented rules had any impact on the saturation and service level of the parking lots, in this paper in specific for South 3 and South 4 parking lots.

One of the KPI's that it would be critical for the impact assessment of the rules implemented, is the parking utilization factor with respect to time, which helps us to see the number of parking places that are occupied (or empty) at throughout the day

Other relevant KPI, is the number of users who cannot find a space to park after crossing the entry gate and, if they are tolerant of waiting, the amount of time it would take to find a place, both measures directly connected with the service level provided.

In summary we have the following output variables:

- Number of users not served because of saturation (parking spaces not available) of the system over a day.

- Maximum number of users waiting for a parking space at the same time (equivalent to a queue after crossing the entrance gate).

- Average search (waiting) time to park in case of saturation.

- Number of parking spaces occupied throughout the day.

\subsection{Simulation model}

The simulation model is based on the process diagram shown in Figure 3, each of the steps shown in this figure was implemented in the model.

In the present section, the processes that require a greater level of detail are described, these are:

1. Entrance to the parking lot,

2. Search and use of a parking space,

3. Exit from the parking lot.

The process to enter the parking lot consists of the following activities:

- Users' arrival in his/her car to the parking lot.

- If the parking gate entrance is available, then the user taps his/her card to access the parking lot.

- If the parking gate entrance is not available, then the user waits until it is available. 
- Once the user has tapped his/her card, he/she enters the parking lot.

The flow diagram for the process to enter the parking lots is provided in Figure 4. As we can see in the diagram, this process concludes with the beginning of the process of searching (waiting inside) and occupation of a parking space, which is denoted by the symbol I.

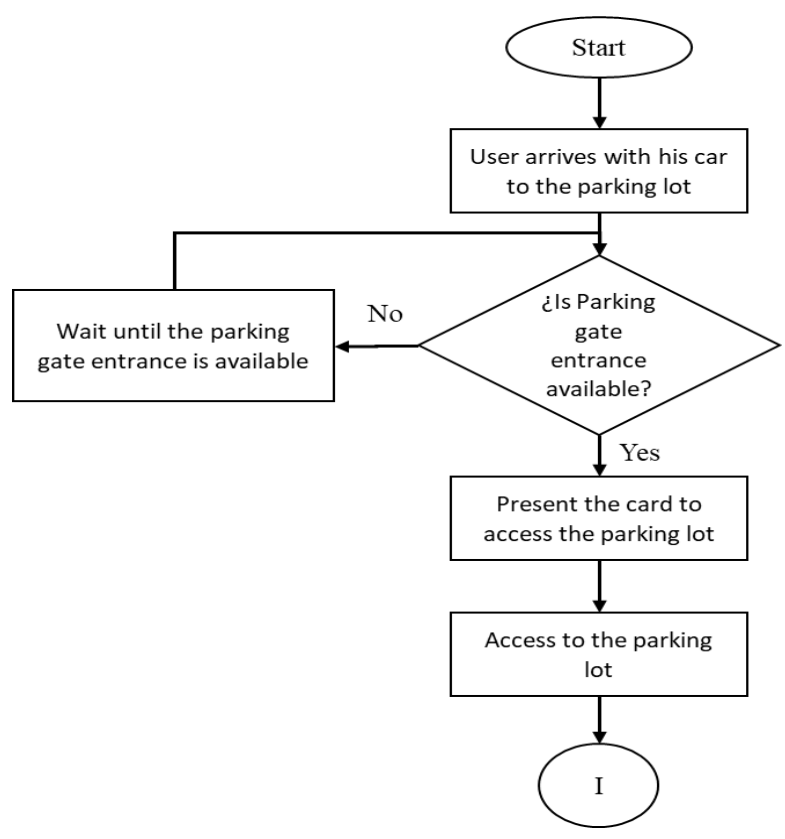

Figure 4: Process flow diagram to enter the parking lots in the Faculty of Engineering, UNAM, Mexico City

The process to search (waiting inside if neeed) and occupy of a parking space, comprises the following activities:

- Search for a parking space.

- If parking space is available, then user occupies the parking space during the required time.

- If parking space is not available, then user wait until a parking space is available.

Process to search and use of a parking space finish with the beginning of process exit from the parking lot.

This can be seen in Figure 5, which shows the activities that make up the process of searching and using a parking space, and the beginning of the parking exit process is denoted by the symbol II.

The process to exit from the parking lot, consists of the following activities:

- Leave the parking space and go to the exit of the parking lot.

- If the parking gate exit is available, then user presents his card to exit of the parking lot.
- If the parking gate entrance is not available, then user waits until it is available.

- Exit to the parking lot.

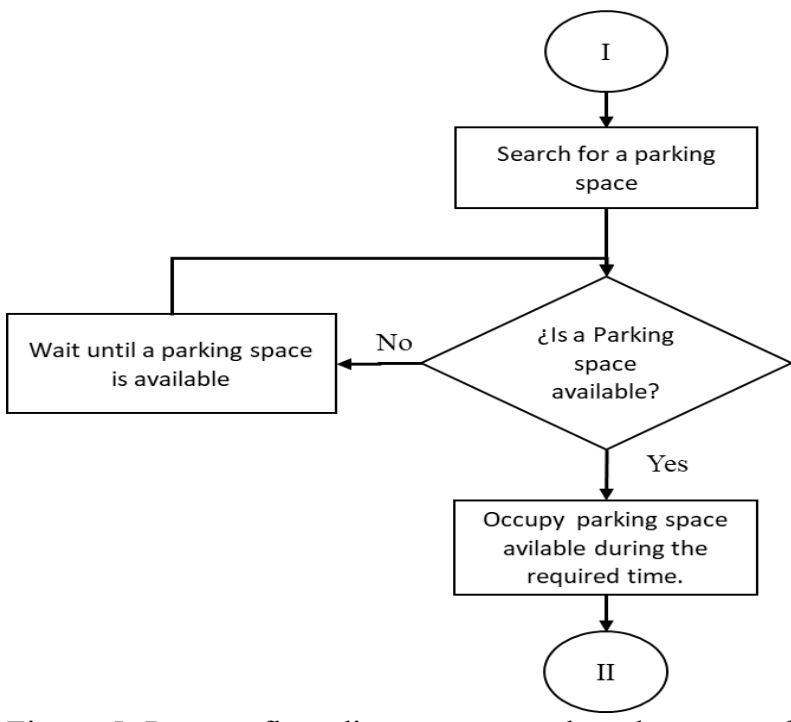

Figure 5: Process flow diagram to search and occupy of a parking space in the Faculty of Engineering, UNAM, Mexico City

The process flow diagram to exit the parking lots is illustrated in Figure 6.

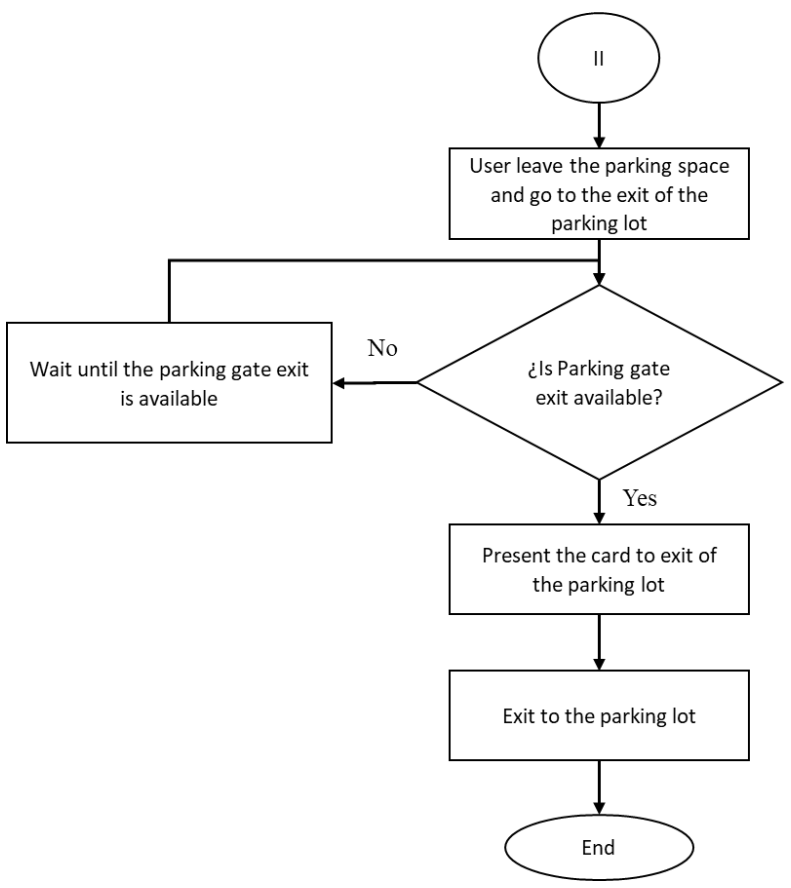

Figure 6: Process flow diagram to exit the parking lots in the Faculty of Engineering, UNAM, Mexico City

Based on the process described above, these processes were modeled under a discrete event simulation approach, then were formalized and implemented in the simulation platform FlexSim ${ }^{\circledR}$, which among other advantages, has the characteristics required for simulation of discrete event systems, some of these are: 
- Model the times between arrivals with distribution functions or with a schedule of arrivals.

- Label the elements that enter the system and differentiate the processing times by type of element.

- Collection of aggregated statistics or time series.

The elements included into the model and its correspondence or meaning to the real system are listed below, the following FlexSim ${ }^{\circledR}$ elements were used:

Source: Used to model the income of the users to the parking lot.

Queues: Used to model the wait of users in cases where the parking gate entrance, parking spaces and the parking gate exit are not available.

Processors: Used to model the service times of the parking gates (entrance and exit) and the dwell times in the parking spaces.

Figure 7 shows the model implemented in FlexSim ${ }^{\circledR}$ in its interface for software's version 2018.

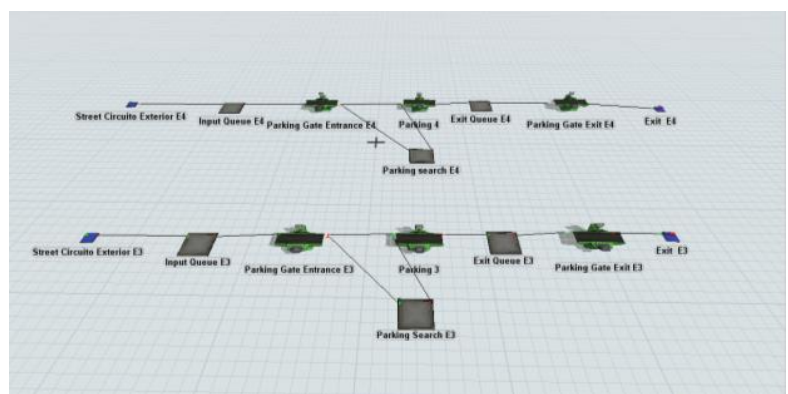

Figure 7: Parking lot model in FlexSim $\AA$, for South 3 and South 4 of the Faculty of Engineering, UNAM, Mexico City

\subsection{Data collection and analysis}

For the data collection, we used the classification proposed by (Harrell, Ghosh and Bowden 2004), which typifies the data in:

- Structural data, these involve all the objects in the system to be modeled.

- Operational data, these data explain how the system operates.

- Numerical data provide quantitative information about the system.

The structural and operational data were obtained through information provided by the parking management and direct observation of the operation of the parking lots. These data correspond to some of the activities reflected in the flow diagrams (Figures 4,5 and 6).

The numerical data to be collected are the following:
- Numbers of parking spaces.

- Service times of the entrance and exit gates

- Arrival times of the users.

- User dwell times.

The number of parking spaces was provided by the administration of the parking lots, from the information provided, it is worthy to highlight the consideration of parking spaces for users with disabilities, however in this first version of the model this characteristic was not included, additionally during direct observation, it was identified that some users may park in spaces that are not marked as suitable for parking, this information is summarized in Table 2.

Table 2: Parking spaces for parking lots South 3 and South 4 of the Faculty of Engineering, UNAM, Mexico City

\begin{tabular}{|c|c|c|c|}
\hline \multirow{2}{*}{$\begin{array}{c}\text { Parking } \\
\text { lot }\end{array}$} & \multicolumn{3}{|c|}{ Parking spaces } \\
\cline { 2 - 4 } & All users & $\begin{array}{c}\text { Disabled } \\
\text { users }\end{array}$ & $\begin{array}{c}\text { Unlabeled } \\
\text { spaces }\end{array}$ \\
\hline South 3 & 182 & 4 & 5 \\
\hline South 4 & 54 & 1 & 2 \\
\hline
\end{tabular}

The service times of the entry and exit gates were collected, this information was analyzed using independence tests and the data were adjusted through goodness of fit tests, all these tests were applied using the ExpertFit ${ }^{\circledR}$ statistical program. The results of goodness of fit tests are shown in Table 3.

Table 3: Service Time distribution in seconds for parking gates, of the parking lots South 3 and South 4 of the Faculty of Engineering, UNAM, Mexico City

\begin{tabular}{|c|c|}
\hline Parking Gate & $\begin{array}{l}\text { Service Time distribution } \\
\text { (seconds) }\end{array}$ \\
\hline $\begin{array}{l}\text { South } 3 \\
\text { entrance }\end{array}$ & $\begin{array}{c}\text { Loglogistic (4.04842, } 6.12395, \\
2.64871)\end{array}$ \\
\hline South 3 exit & $\begin{array}{c}\text { Lognormal }(6.0512,7.87486, \\
0.57084)\end{array}$ \\
\hline $\begin{array}{l}\text { South } 4 \\
\text { entrance }\end{array}$ & $\begin{array}{c}\text { Beta }(6.894,47.4926,1.3725, \\
6.13798)\end{array}$ \\
\hline South 4 exit & $\begin{array}{c}\text { Johnson }(9.41334,56.8009 \\
2.02019,0.9954)\end{array}$ \\
\hline
\end{tabular}

Concerning to user's arrival and dwell times, the administration of parking lots provided the information of entrance and exit gates records for each of the eight parking lots, including South 3 and South 4, which comprise years 2015, 2016 and 2017.

Data provided for each event recorded at the entrance and exit gates are:

- Card number

- Date

- Hour (hours, minutes and seconds) 
Once these data were obtained, we proceeded to clean the provided databases, during the data cleaning process some of the inconsistencies found were:

- Cards with entry and not exit records.

- Cards with exit and not entry records.

- Duplicate records for both entry and exit.

Once the databases were cleaned and structured for our study, we proceeded to calculate the dwell times by the difference of the time of entry and exit of the cards. Dwell and arrival times were entered the model for each of the users.

The assumptions used in the model are:

- Users wait until they find a parking spot. This assumption allows to determine the capacity shortages along the day.

- The time in which the users present their card to access the parking lots are considered as the arrival time of the users.

\subsection{Scenarios and experiments}

Scenarios were identified from historical data, since the research aim is to verify the impact of the application of the new restrictions to part time instructor, the scenarios seeks to show the performance before and after the adoption of the rules by means of measuring the KPIs.

That is, since the changes in the operating rules were made in July 2016, the operation of the system for the years 2015 and 2017 will be analyzed.

2015 is analyzed the KPIs when the users had free access independent of the type, and 2017 to analyze the impact after access restrictions by user type took effect.

For both Scenarios (years) an entire week of data (behavior for 5 days) is analyzed, for the election of this week the following steps were followed:

1. Identification of the month with the highest number of events (user occupying the parking lot).

2. Identification of the busiest week among the month, it is, once we have the month with the highest number of events, select the week with the highest number of events.

The number of events per month considering both parking lots (South 3 and South 4) for the years 2015 and 2017 are shown in Table 4.

Table 4: Monthly number of events for parking lots South 3 and South 4 of the Faculty of Engineering, UNAM, Mexico City

\begin{tabular}{|c|c|c|}
\hline \multirow{2}{*}{ Month } & \multicolumn{2}{|c|}{ Number of events } \\
\cline { 2 - 3 } & 2015 & 2017 \\
\hline JAN & 10,152 & 8,801 \\
\hline
\end{tabular}

\begin{tabular}{|c|c|c|}
\hline FEB & 11,423 & 10,118 \\
\hline MAR & 11,549 & 11,484 \\
\hline APR & 10,211 & 8,669 \\
\hline MAY & 7,628 & 10,671 \\
\hline JUN & 11,635 & 11,259 \\
\hline JUL & 4,728 & 3,099 \\
\hline AUG & 11,832 & 12,858 \\
\hline SEP & 11,870 & 9,240 \\
\hline OCT & 13,021 & 12,329 \\
\hline NOV & 11,137 & 10,913 \\
\hline DEC & 5,245 & 5,485 \\
\hline
\end{tabular}

For the year 2015, the October has the highest number of events with 13,021, while for 2017, August has the highest number with 12,858 .

Weekly events breakdown for selected months (October 2015 and August 2017) are shown in Table 5 and Table 6.

Table 5: Weekly number of events for parking lots South 3 and South 4, October 2015 of the Faculty of Engineering, UNAM, Mexico City

\begin{tabular}{|c|c|}
\hline Week October 2015 & Number of events \\
\hline 1 to 4 & 1,165 \\
\hline 5 to 11 & 2,903 \\
\hline 12 to 18 & 2,825 \\
\hline 19 to 25 & 2,925 \\
\hline 26 to 31 & 2,875 \\
\hline
\end{tabular}

Table 6: Weekly number of events for parking lots South 3 and South 4, August 2017 of the Faculty of Engineering, UNAM, Mexico City

\begin{tabular}{|c|c|}
\hline Week August 2017 & Number of events \\
\hline 1 to 6 & 1,801 \\
\hline 7 to 13 & 2,698 \\
\hline 14 to 20 & 2,831 \\
\hline 21 to 27 & 2,760 \\
\hline 28 to 31 & 2,232 \\
\hline
\end{tabular}

From the above selection criteria and the numbers, the selected week (days) for October 2015 would be from 19 to 25, 2015, and for the year 2017 from August 14 to 20, 2017.

\section{RESULTS}

The key performance indicators (KPI's) for the selected weeks during 2015 and 2017 are shown in Table 7 and 8 respectively. Saturdays and Sundays were excluded, since these days the results of the simulation showed a utilization of less than $50 \%$.

In these tables the following abbreviations are used:

NUNS- Number of users not served due to saturation (parking places not available) of the system over a day.

MNUS- Maximum number of users looking for a parking space at the same time. 
AST- Average search time of a parking space in case of saturation.

HSS- It refers to the periods of time (range) in which the utilization of parking was above $95 \%$, this parameter was defined together with the administration of the parking lots.

NA- Not applicable

From the results obtained for the analyzed weeks, there is an increase of saturation level of the South Parking Lot 3 , this is observed by comparing year 2015 vs the year 2017, as for the South 4 parking lot, it is detected that never reached a utilization higher that $95 \%$, thus is never saturated.

Another interesting data obtained from the scenarios simulated, is the Average Dwell Time in the South 3 and South 4 parking lots. As is shown in Table 9, this time has decreased from 2015 to 2017 in both parking lots.

The evolution of the utilization of along the day, is illustrated with the time series of the parking spaces occupied for the South 3 and South 4 parking lots. Figure 8 provides an example of this analysis for August 17, 2017. From the plot, is easy to realize that capacity shortages at South 3 parking lot could be avoided by using as supplement the latent capacity of the South 4 parking lot.

Finally, from a straight comparison of the defined KPI's (NUNS, MNUS, AST and HSS), observed in the worse cases for both experiments (2015 and 2017), the numbers for 2015 are systematically lower, which reveals a better service and performance.

From the above, it is questionable to assume a positive effect of those restrictions introduced as improvement actions, it is important to highlight that the demand is growing. Then, unless it is considered an additional adjustment to rebalance the demand, by using both facilities in an integrated way (South 3 and 4), using South 4 as a supplement source of capacity, the service level is predicted to be worsen in the following year of operation.

Table 7: Key Performance Indicators (KPI's) for parking lots South 3 and South 4 of the Faculty of Engineering, UNAM, Mexico City, October 19 to 23, 2015

\begin{tabular}{|c|c|c|c|}
\hline \multicolumn{4}{|c|}{ October 19 to 23, 2015 } \\
\hline \multirow{4}{*}{ Day } & $\begin{array}{c}\text { Parking } \\
\text { Lot }\end{array}$ & KPI & Value or Range \\
\hline \multirow{4}{*}{$\begin{array}{c}\text { October } \\
19\end{array}$} & \multirow{3}{*}{ South 3 } & NUNS & 13 users \\
\cline { 3 - 4 } & & MNUS & 4 users \\
\cline { 3 - 4 } & & AST & $439.7 \mathrm{~s}$ \\
\cline { 3 - 4 } & \multirow{3}{*}{ South 4 } & NUNS & $11: 13$ a 13:35 h \\
\cline { 3 - 4 } & & MNUS & NA \\
\cline { 3 - 4 } & & AST & NA \\
\hline
\end{tabular}

\begin{tabular}{|c|c|c|c|}
\hline & & $\mathrm{HSS}$ & NA \\
\hline \multirow{8}{*}{$\begin{array}{c}\text { October } \\
20\end{array}$} & \multirow{4}{*}{ South 3} & NUNS & 37 users \\
\hline & & MNUS & 7 users \\
\hline & & AST & $443.8 \mathrm{~s}$ \\
\hline & & HSS & $11: 08$ a $14: 21 \mathrm{~h}$ \\
\hline & \multirow{4}{*}{ South 4} & NUNS & NA \\
\hline & & MNUS & NA \\
\hline & & $\mathrm{AST}$ & NA \\
\hline & & HSS & NA \\
\hline \multirow{8}{*}{$\begin{array}{c}\text { October } \\
21\end{array}$} & \multirow{4}{*}{ South 3} & NUNS & NA \\
\hline & & MNUS & NA \\
\hline & & $\mathrm{AST}$ & NA \\
\hline & & HSS & $11: 45$ a $12: 43 \mathrm{~h}$ \\
\hline & \multirow{4}{*}{ South 4} & NUNS & NA \\
\hline & & MNUS & NA \\
\hline & & $\mathrm{AST}$ & NA \\
\hline & & HSS & NA \\
\hline \multirow{8}{*}{$\begin{array}{c}\text { October } \\
22\end{array}$} & \multirow{4}{*}{ South 3} & NUNS & NA \\
\hline & & MNUS & NA \\
\hline & & $\mathrm{AST}$ & NA \\
\hline & & HSS & $11: 46$ a $13: 38 \mathrm{~h}$ \\
\hline & \multirow{4}{*}{ South 4} & NUNS & NA \\
\hline & & MNUS & NA \\
\hline & & $\mathrm{AST}$ & NA \\
\hline & & $\mathrm{HSS}$ & NA \\
\hline \multirow{8}{*}{$\begin{array}{c}\text { October } \\
23\end{array}$} & \multirow{4}{*}{ South 3} & NUNS & NA \\
\hline & & MNUS & NA \\
\hline & & $\mathrm{AST}$ & NA \\
\hline & & HSS & 11:00 a 13:04 h \\
\hline & \multirow{4}{*}{ South 4} & NUNS & NA \\
\hline & & MNUS & NA \\
\hline & & $\mathrm{AST}$ & NA \\
\hline & & HSS & NA \\
\hline
\end{tabular}

Table 8: Key Performance Indicators (KPI's) for parking lots South 3 and South 4 of the Faculty of Engineering, UNAM, Mexico City, August 14 to 18, 2017

\begin{tabular}{|c|c|c|c|}
\hline \multicolumn{4}{|c|}{ August 14 to 20,2017} \\
\hline Day & $\begin{array}{c}\text { Parking } \\
\text { Lot }\end{array}$ & KPI & Value or Range \\
\hline \multirow{8}{*}{$\begin{array}{c}\text { August } \\
14\end{array}$} & \multirow{4}{*}{ South 3} & NUNS & 64 users \\
\hline & & MNUS & 19 users \\
\hline & & $\mathrm{AST}$ & $1,400.46 \mathrm{~s}$ \\
\hline & & HSS & $10: 47$ a $14: 19 \mathrm{~h}$ \\
\hline & \multirow{4}{*}{ South 4} & NUNS & NA \\
\hline & & MNUS & NA \\
\hline & & AST & NA \\
\hline & & HSS & NA \\
\hline \multirow{8}{*}{$\begin{array}{c}\text { August } \\
15\end{array}$} & \multirow{4}{*}{ South 3} & NUNS & 97 users \\
\hline & & MNUS & 35 users \\
\hline & & $\mathrm{AST}$ & $2,222.11 \mathrm{~s}$ \\
\hline & & HSS & $10: 42$ a $14: 32 \mathrm{~h}$ \\
\hline & \multirow{4}{*}{ South 4} & NUNS & NA \\
\hline & & MNUS & NA \\
\hline & & AST & NA \\
\hline & & HSS & NA \\
\hline
\end{tabular}




\begin{tabular}{|c|c|c|c|}
\hline \multirow{8}{*}{$\begin{array}{c}\text { August } \\
16\end{array}$} & \multirow{4}{*}{ South 3} & NUNS & 86 users \\
\hline & & MNUS & 25 users \\
\hline & & AST & $1,439.22 \mathrm{~s}$ \\
\hline & & HSS & $10: 34$ a $14: 21 \mathrm{~h}$ \\
\hline & \multirow{4}{*}{ South 4} & NUNS & NA \\
\hline & & MNUS & NA \\
\hline & & AST & NA \\
\hline & & HSS & NA \\
\hline \multirow{8}{*}{$\begin{array}{c}\text { August } \\
17\end{array}$} & \multirow{4}{*}{ South 3} & NUNS & 101 users \\
\hline & & MNUS & 31 users \\
\hline & & AST & $2,881.96 \mathrm{~s}$ \\
\hline & & HSS & $10: 31$ a $14: 52 \mathrm{~h}$ \\
\hline & \multirow{4}{*}{ South 4} & NUNS & NA \\
\hline & & MNUS & NA \\
\hline & & AST & NA \\
\hline & & HSS & NA \\
\hline \multirow{8}{*}{$\begin{array}{c}\text { August } \\
18\end{array}$} & \multirow{4}{*}{ South 3} & NUNS & 75 users \\
\hline & & MNUS & 14 users \\
\hline & & AST & $1.075 .14 \mathrm{~s}$ \\
\hline & & HSS & $10: 43$ a $14: 25 \mathrm{~h}$ \\
\hline & \multirow{4}{*}{ South 4} & NUNS & NA \\
\hline & & MNUS & NA \\
\hline & & AST & NA \\
\hline & & HSS & NA \\
\hline
\end{tabular}

Table 9: Average Dwell Time for parking lots South 3 and South 4 of the Faculty of Engineering, UNAM, Mexico City, October 20,2015 \& August 17, 2017

\begin{tabular}{|c|c|c|}
\hline Day & $\begin{array}{c}\text { Parking } \\
\text { Lot }\end{array}$ & $\begin{array}{c}\text { Average Dwell } \\
\text { Time (s) }\end{array}$ \\
\hline \multirow{2}{*}{20 October 2015 } & South 3 & $15,286.8$ \\
\cline { 2 - 3 } & South 4 & $12,396.6$ \\
\hline \multirow{2}{*}{ 17 August 2017 } & South 3 & $14,880.7$ \\
\cline { 2 - 3 } & South 4 & $11,111.7$ \\
\hline
\end{tabular}

\section{WIP Vs Time Parking Lots South 3 and South 4}

- Estacionamiento 3 | Estacionamiento 4

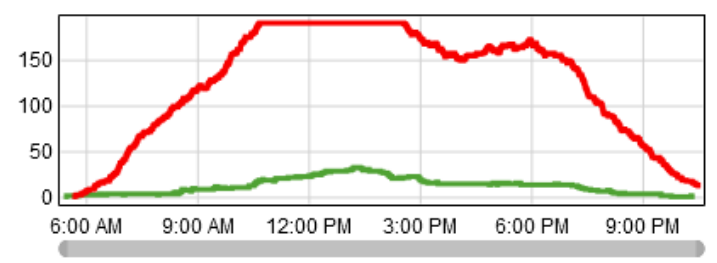

Figure 8: Time series of the parking spaces occupied for the South 3 and South 4 parking lots of the Faculty of Engineering, UNAM, Mexico City, August 17, 2017

\section{CONCLUSIONES}

The implementation of the discrete event simulation models of the parking lots, allowed to have a better understanding of their operation.

With respect to the analysis of the results obtained with the changes in the access policy by user type. The changes in the policy do not have a positive impact on a decrease of the saturation of the parking lots, although for the South 3 and South 4 parking there is a decrease in the dwell times (Table 9), at the same time there was an increase in the number of users in the case of South 3 parking and a decrease in the number of users in the case of South 4 parking.

For the demand of the week from August 14 to 20,2017 (Monday to Friday), the period with the highest saturation (occupied parking spaces greater than $95 \%$ of the capacity) for parking lot South 3, occurs between 10:30 and 3:00 p.m.

To improve the level of service with respect to the parking utilization factor, it is necessary to establish a policy that allows assigning the parking lots to which users will have access based on the building in which they have their workplace (office, classroom or laboratory), but taking in to account the integrated capacity of the parking lots and not as independent resources. This policy can be tested with the simulation model developed as part of this research paper, its implementations may require minor updated and modifications.

\section{FUTURE WORK}

The School of Engineering has eight parking lots, these could be divided into two subsystems with four parking lots each, depending on the proximity and the population they serve. Two models should be developed to allow testing and analyzing parking allocation policies based on the location of the workplace (office, classroom or laboratory) and type of user.

\section{ACKNOWLEDGMENTS}

This work was supported by UNAM-DGAPAPAPIME, PAPIME PE102218 "Preparation of didactic material (notes, presentations, exercise series and study cases) and online courses regarding Simulation of Complex Systems and Business Intelligence (Business Intelligence)." Also Dr. Nosedal is supported by the Mexican National Science and Technology Council (CONACYT) (project 2354).

\section{REFERENCES}

Barata, E., Cruz, L., \& Ferreira, J. P. (2011). Parking at the UC campus: Problems and solutions. Cities, 28(5), 406-413.

FlexSim (2018) https://www.flexsim.com/

Fontaine, Michael \& E. Isler, Elizabeth \& A. Hoel, Lester. (2005). Innovative Parking Management Strategies for Universities: Accommodating Multiple Objectives in a Constrained Environment.

Harrel C., Gosh B.K., Bowden R. (2004). Simulation Using Promodel, 2nd Edition, Mc Graw-Hill, New York. 128-129.

Sweet, M. N., \& Ferguson, M. R. (2019). Parking demand management in a relatively uncongested university setting. Case Studies on Transport Policy.

Teodorović, D., \& Lučić, P. (2006). Intelligent parking systems. European Journal of Operational Research, 175(3), 1666-1681. 
Yan, X., Levine, J., \& Marans, R. (2019). The effectiveness of parking policies to reduce parking demand pressure and car use. Transport Policy, 73, 41-50.

\section{AUTHORS BIOGRAPHY}

Ricardo Torres, studied Industrial Engineering, then a Master Financial Optimization and Planning at the Engineering Faculty in UNAM (Mexico). His lines of research are Simulation, and Replenishment systems in Supply Chain.

Jenaro Nosedal-Sanchez holds a Ph.D. in Telecommunications and Systems Engineering from Univesitat Autónoma de Barcelona, Spain. $\mathrm{He}$ is currently Research Fellow for the National Science and Technology Council (CONACYT-Mexico), within the "Cátedras Conacyt" program. Since July 2018 was appointed as Lecturer at the Masters in Supply Chain Engineering program at Mexico State Autonomous University. His research interests include modeling and applied simulations, optimization, operations management and humanitarian logistics. 